\title{
Research on the Target Connotation and Hierarchical Positioning of English and American Literature Teaching
}

\author{
Jing Zhang \\ Changchun Sci-Tech University, Jilin, Changchun, 130600
}

\begin{abstract}
Keywords: target connotation, hierarchical positioning, English and American literature teaching
\end{abstract}
\begin{abstract}
With the continuous development of the market economy and curriculum reform, as the pillar course of English major, the teaching of English and American literature faces unprecedented pressure and challenges. A new analysis and positioning of the target connotation of English and American literature teaching is not only an objective requirement for the in-depth development of the market economy and curriculum reform, but also an important measure to enhance the teaching level and enhance the comprehensive English strength of students. This paper starts with the current situation of English and American literature teaching, and elaborates on the specific content of its target connotation and hierarchical orientation, and puts forward specific suggestions on the future development path and direction of English and American literature teaching.
\end{abstract}

\section{Introduction}

In the past ten years, the external environment and internal structure of China's higher education have undergone tremendous changes. The export-oriented economy has developed rapidly. The employment of college students has shifted from the traditional distribution type to the market selection type. Undergraduate education has gradually changed from a specialized education to a generalist. Education, postgraduate education has become the main channel for cultivating research professionals. The teaching of English and American literature, which was once the main pillar of the English major, faced increasing challenges. The main problem is that a large number of students turn their enthusiasm for learning into practical courses that have a great relationship with the market and help employment, such as foreign trade English, business English, legal English, and travel English. The literary curriculum has been left out, and it is an unavoidable fact [1].

\section{The Current Situation of English and American Literature Teaching}

Nowadays, the curriculum of English and American literature has a single structure, and it is still in the stage of systematic teaching in the teaching of English and American literature. Although it is available in the textbooks, the distribution of knowledge points is too cumbersome and complicated, and students cannot find a key entry point in the complicated knowledge. For example, in the literature selection class, the teaching is started from the classical works, but the students have no matching language ability, and the reference in the course is imprisoned. Although the teacher analyzes the lectures in detail, but the students are limited in their ability, the wonderful literature. The disintegration of the works is lost, and the unique artistic charm of the literary works is lost. The mechanical teaching mode must be changed. Modern teaching should combine humanistic care with high-quality aesthetic tastes, and cultivate excellent modern personality. Targeted teaching will enable students to be sublimated in the teaching of English and American literature.

With the development of curriculum reform and the changes in market economy demand, the goal orientation of English and American literature teaching in colleges and universities is becoming vague and the process of educational function is hindered [2].

The educational function of English and American literature is mainly to guide students through reading English and American literary works, effectively grasp the deep content of language, and encourage students to obtain more effective information and knowledge from literary works, and promote the comprehensive improvement of English knowledge level and ability. However, from 
the current situation of English and American literature teaching, there is a widespread problem of single curriculum and boring teaching content, which is difficult to stimulate students' interest in reading English and American literature.

Although some English and American literature teachers in colleges and universities are aware of the goal of teaching, they do not form a correct understanding of the related content such as hierarchical positioning. They simply believe that the main task of teaching is to guide students to develop reading habits and neglect students. The evaluation and learning of the connotation and spiritual value of the work, the student's learning state is only in the passive stage, it is difficult to form an active inquiry consciousness for literary works.

\section{The Teaching Objectives of English and American Literature}

The teaching objectives of English and American literature should be considered comprehensively. There are many issues to be considered. First, we must establish what courses we need to carry out. From which stage of the course, what courses can be compulsory, and what courses are positioned and elective. In the elective course, we must also focus on the improvement of students' abilities and how to choose in literary history and monographs. In the current colleges and universities, the teaching structure is usually selected as the orthodox teaching trend with the history of English and American literature and literary works. Generally speaking, it is based on the preference for the history of English and American literature, which leads to the lack of theoretical knowledge and criticism of English and American literature. This kind of teaching structure has a comprehensive understanding of the literary development chain. In order to make innovations in the current teaching goals, it is necessary to draw on the latest research results at home and abroad to redefine the new teaching model. First of all, the history of mankind is constantly advancing, as is the case with British and American literature. The history chain of British and American literature should pay attention to the details of the branch. The research results of British and American literary works at home and abroad are gradually increasing. Not only are the works of mainstream writers, but nowadays the works of non-mainstream writers have also received attention, such as minority works and female writers. Therefore, it is necessary to make teaching innovations for the current branch literature so as to follow into the new era of English and American literature teaching. At present, major universities are gradually adding new courses, and the compulsory courses have been gradually reduced. Many English majors or graduates of English and American literature courses will not engage in related work after graduation, so we must reform the teaching content and teaching according to the actual situation. The order is to make different tasks and goals for different students, and put the teaching focus on the targeted teaching mode, so that students can freely gain the English literature ability. At present, English and American literature teaching should also pay attention to a key goal. Nowadays, linguistics and literature courses and special English (ESP) have already been opposed. It is necessary to consider the focus of students' learning. In the focus of English and American literature teaching, students should be emphasized and interpret English and American [3].

Under the premise of the new curriculum reform and the continuous development of the market economy in China, at this stage, there is no clear goal in the teaching of English and American literature in college English majors in China, so it is impossible to specifically measure the teaching effect. Students lack the initiative to learn, but passively accept the knowledge instilled by teachers, and lack the ability of independent inquiry and independent inquiry. Therefore, teachers need to clarify the teaching objectives and hierarchical positioning. The new curriculum standard expresses the teaching objectives and hierarchical orientation of English and American literature, which is to cultivate students' appreciation and understanding of the original English literature and master the methods of literary criticism. Through the analysis of English and American literary works, students' ability to control language is enhanced, and students have a better understanding of British and American culture.

First, guide students to read and cultivate students' interest in English and American literature. The foundation of English and American literature teaching is to guide students to read and let 
students form their own reading experience. Through the student's reading experience, students' reading interest and enthusiasm for learning can be cultivated. At the same time, it will also develop good habits for students to read. If students have always had good reading habits, the harvesting experience will be very rich. On this basis, students can continuously expand and arm their own knowledge systems. When students' knowledge accumulation reaches a certain level, students will form themselves. In addition, by reading students' continuous reading methods, they can not only improve their own learning ability, but also have a strong interest in English and American literature.

Second, guide students to master the basic knowledge and gain general knowledge of English and American literature. Through the reading of English and American literature, students can increase the basic knowledge of English and American literature. An English and American literary work is equivalent to a large humanistic system. Students can master the basic knowledge of English and American literature through reading. Students' mastery of basic knowledge is also a testimony to the reading effect. The basic knowledge of English and American literature belongs to the knowledge of the rational level. Teachers should strengthen the guidance for students let students understand the development history of English and American literature and the literary phenomenon of special periods. Students can gain the general knowledge of English and American literature in the process of reading, which can be expanded to a certain extent.

Third, students master effective reading methods and improve their overall quality. With the promulgation of the new curriculum standard, students must master effective reading methods to improve the overall quality of students. Specifically, students are allowed to interpret the spiritual value of literary works, so that students' understanding and expression skills are improved. At the same time, students can constantly improve their knowledge system. If students' knowledge accumulation is higher, they will form a unique view, which will enhance the overall quality of students [4].

Fourth, the quality of local people can be tapped by reading English and American literature. Literary works generally imply the character of people in a country or region. Literary works are like a window. We can visually see the structure of literary works, and understand the folklore and people's character contained in literary works through construction. Thus the essence is seen through the phenomenon. British and American literature has such a magical effect. After students master the spiritual connotation of literary works, they can clarify the character of British and American people and understand the human history of a country.

Fifth, through the understanding of human history, cultivate students' humanistic feelings. Through the teaching of English and American literature, students can cultivate and enhance their humanistic feelings. Because students can understand the humanistic history and national character of a country, it will enhance the perception and insight of students' thinking, so that students' knowledge can be expanded, life's sentiment can be enriched, and students' comprehensive quality can be improved.

\section{The Hierarchical Positioning of English and American Literature}

In the English and American literature courses, we must find the direction of teaching and make a level of positioning in order to improve students' English proficiency. At the first level, all students should be offered public elective courses. Most of the current college students already have good English proficiency. In terms of innovation, they should focus on improving the language application ability and enhance the humanities literacy and English literature cognition. The main purpose is not to make students simple. The examination, but at the deep level, comprehensively enhance students' English literacy. The second level is to carry out professional basic courses in the course, which is suitable for students in all directions. At this level, it is necessary to aim at the basic knowledge and classic works of English and American literature, and then assist in the compilation of teaching materials and teaching materials. In the daily teaching, I choose famous famous British and American literary classics, so that students can read English and American literary novels and dramas at any time. Make trade-offs between foundations and extracurricular 
readings, complement each other, and realize the common development of literature and entertainment in daily teaching. At the third level, professional elective courses should be offered to individual students who have a preference for academic interest, and then they should be considered according to the specific school and teaching conditions. At this level, the focus should be on the methods of knowledge and literary criticism of English and American literature. It is to make a practical analysis of British and American literary works, and strive to let students master the ability and methods of literary criticism, and work hard on students' theoretical cultivation and aesthetic improvement.

After teachers understand the teaching objectives and hierarchical positioning, they can take effective measures to carry out teaching activities. In the realization of the teaching objectives and hierarchical positioning of English and American literature, it can be realized through scientific curriculum setting, and the basic knowledge of literature and reading experience can be set as the main line. While offering courses such as "An Introduction to Anglo-American Literature" or "Selected Readings of English and American Literature", a wide range of professional elective courses can be offered. The courses include "Appreciation of English and American Poetry" and "Appreciation of Anglo-American Films" to give English majors a sense of literature. Interested students can learn more about English and American literature [5].

Through teaching, we can improve the literacy of students. At the same time, students can make extensive exposure to different types of literary works and open up their own horizons. The course should be based on the students' different interests and consult the students to conduct more targeted teaching. Traditional indoctrinating teaching methods have poor teaching effects. Therefore, it is necessary to reform and innovate teaching methods. Through a variety of teaching methods, students can create a good teaching environment, and students can better read and absorb knowledge. For example, a teacher can design a specific situation according to the specific content of the teaching, and the student can understand the literary works through a specific situation to achieve a better teaching effect.

\section{Conclusion}

In summary, on the basis of China's education reform, it is necessary to analyze the teaching objectives and hierarchical positioning of English and American literature, so as to better find effective teaching strategies. This paper mainly analyzes the teaching objectives and hierarchical orientation of English and American literature, and explores the specific implementation strategies. I hope that through the research of this article, it will help the realization of the teaching objectives of English and American literature.

\section{References}

[1] Hong Wenhui. Deepening the Humanistic Connotation of English and American Literature Teaching with Action Orientation [J]. Foreign Languages Research, 2017(02).112

[2] Yang Bing. On the Teaching of English and American Literature in the Multimedia Environment [J]. Literature Education (2), 2017(06).56

[3] Liu Min. The auxiliary role of English film in the teaching of English and American literature in college English [J]. Overseas English, 2013(2): 3-4.

[4] Cao Liqun. On Cultural Teaching in English and American Literature Courses-Taking Franklin's Autobiography as an Example [J]. Journal of Shaoxing University of Arts and Sciences (Education and Teaching Research), 2013(1): 48-50.

[5] Tian Jing. Research on the Cultivation of English Majors' Humanities Quality in English and American Literature Teaching [J]. China Electric Power Education, 2013(19): 225-226. 